\title{
Zen, Motorcycles and Burning Buddhas
}

\author{
CHRISTIAN WITTERN \\ Kyoto University \\ cwittern@gmail.com
}

Abstract: The standard narrative of the relationship of religion and science presents science as wrangling domination from the realm of religion, which is clouded in dogma, by using the rational mindset of enlightenment, a sophisticated method which is designed to discover the truth about our world and ourself.

In this paper, I would like to turn this story on its head and show how science today is marred in dogma, unable to move beyond a very narrow conception of reality, supporting a worldview that is bound to crash full speed into the boundaries of our planet and taking most life forms with it.

Buddhism, on the other hand, will emerge as providing one possible path to move beyond the limitations of these dogmas and engage with our planet and all its lifeforms in the only meaningful way possible: As a relationship based on loving-kindness, rooted in the first hand experience of the inter-connectiveness of all beings and the intimate, heartfelt love based on this. Buddhism, is of course not the only worldview that takes such a stance, but since it is the topic for this conference, I will focus on Buddhism, more specifically on ChanBuddhism as reflected in the Chan literature of early Song China.

Keywords: Man and nature, history of science, scientific method, Chan Buddhism, Mindfulness

DOI: https://dx.doi.org/10.15239/hijbs.03.02.06 


\begin{abstract}
$A \mathrm{~h}$, what a poor, dry compilation is the 'Annual of Scientific ADiscovery!' I trust that observations are made during the year which are not chronicled there, that some mortal may have caught a glimpse of Nature in some corner of the earth during the year 1851. One sentence of perennial poetry would make me forget, would atone for, volumes of mere science. The astronomer is as blind to the significant phenomena, or the significance of phenomena, as the wood-sawyer who wears glasses to defend his eyes from sawdust. The question is not what you look at, but what you see. ${ }^{1}$
\end{abstract}

If we want to attain a living understanding of nature, we must become as flexible and mobile as nature herself. ${ }^{2}$

I must admit that I have long been suspicious of the great and important-sounding task: 'know thyself. This has always seemed to me a deception practiced by a secret order of priests who wished to confuse humanity with impossible demands, to divert attention from activity in the outer world to some false, inner speculation. The human being knows himself only insofar as he knows the world; he perceives the world only in himself, and himself only in the world. Every new object, clearly seen, opens up a new organ of perception in us. ${ }^{3}$

\title{
Prelude: Science and religion
}

The juxtaposition of science and religion, as it usually seen, ${ }^{4}$ is based on European history and the way the interactions between the

1 Thoreau, The Writings of Henry David Thoreau, 373.

2 Goethe, Scientific Studies, 64.

3 In 'Significant Help Given by an Ingenious Turn of Phrase' (In Goethe, Scientific Studies, 39).

4 The CFP for the conference, to which this paper was submitted, starts with the following sentences: 'Science and religion are, by and large, presented to have different missions, and different paths to fulfill them: Science empha- 
religious institution of the Catholic church ${ }^{5}$ and the new natural philosophy and its proponents of a new world view beyond the dogma of faith played out. The way science developed at this specific time in Europe was strongly influenced by the then-dominant Christian worldview. Before turning a comparative gaze towards Buddhism, it would be appropriate to state a few facts about Buddhism as a religion in comparison with the Catholic church, so as to make clear what aspects are available for comparison. I will recount this from the perspective of my personal recollection, as I believe this has some elements typical to encounters with Buddhism in the West in the 1970s.

One of the first books I encountered with the word 'Zen' in the title was the novel Zen and the Art of Motorcycle Maintenance by Robert M. Pirsig, a book I read many times during my student days. Although a novel in form, it describes a philosophically serious attempt to define 'quality' in the context of objective, rational thinking; thus pointing right at the core of the problem of modernity. In spite of the title, it is not in any sense explicitly about Zen, and indeed the word Zen appears only a couple of times, most prominently in the recount of the protagonist's stay in India to study Oriental Philosophy, but '[h]e'd entered India an empirical scientist, and he left India an empirical scientist', ${ }^{6}$ and in fact all the Indian

sizes rationality and empiricism, whereas religion values emotion and faith. Science is said to be unconcerned about taboos and the sacred, while religion exalts in mystery. The Enlightenment movement in the early modern period is often understood in opposition to the "darkness" of the middle ages when religion was the hegemonial discourse in Europe.' (See 'Buddhism and Technology: Historical Background and Contemporary Challenges', Tianzhu Buddhist Network, 2019, https://tianzhubuddhistnetwork.org/buddhism-and-technology-historical-background-and-contemporary-challenges/.) Although the text continues to put this in a bit more nuanced and goes on to enumerate examples from the history of Buddhism, this remains the context in which the conference is set.

5 I will take the Catholic church here as a representative of the Christian religion, since it has the longest and strongest history of engagement with the scientific thinking, but also because taking other dominitions of the Christian faith will unnecessarily muddy the waters without much gain. 
teachings did seem quite similar to him. In this context, the reader learns that Zen is the Japanese reading of the Chinese Chan, which is derived from Sanskrit dhyana, but he 'never got involved in meditation because it made no sense to him'. ${ }^{7}$ When the professor told him that he believed the atomic bombs dropped on Hiroshima and Nagasaki where as illusory as anything in the world, he gave up and left India. Most memorable is the statement ' $[t]$ he only Zen you find on the tops of mountains is the Zen you bring up there. Let's get out of here. ${ }^{\text {' }}$ Although thus not explicitly about Zen, the mode of inquiry and the attempt to overcome the framework of rational thinking is at the core of the Zen method, laid out not in a theoretical manner, but performed (strictly speaking, a recounting of the performance).

This attitude of relying on once own faculties to encounter the ultimate truth about this world, rather than follow some authoritative scripture or doctrine is also at the core of the message of the Buddha, as for example spelled out in this passage from the Anguttara Nikayya, which is frequently referred to in this context:

Come, Kālāmas, do not go by oral tradition, by lineage of teaching, by hearsay, by a collection of scriptures, by logical reasoning, by inferential reasoning, by reasoned cogitation, by the acceptance of a view after pondering it, by the seeming competence [of a speaker], or because you think: 'The ascetic is our guru'. But when, Kālāmas, you know for yourselves: 'These things are unwholesome; these things are blameworthy; these things are censured by the wise; these things, if accepted and undertaken, lead to harm and suffering', then you should abandon them. ${ }^{9}$

I will return to this, but first I will look very briefly at the scientific method.

6 Pirsig, Zen and the Art of Motorcycle Maintenance, 142.

7 Pirsig, Zen and the Art of Motorcycle Maintenance, 143.

8 Pirsig, Zen and the Art of Motorcycle Maintenance, 251.

9 Bodhi, The Numerical Discourses of the Buddha; Anguttara Nikàya 3: 65, 280. 


\section{Scientific Method}

Buddhism holds that our mental functions preempt and preconfigure our perceptive and analytical facilities, a thought that is especially developed in the Yogacara School. Dan Lusthaus, who made a philosophical investigation into the tenets of Yogacara explains this as follows:

According to Yogācāra our mental experience is changing, altering (parinama, pravrtti) every moment. In this fluctuating stream (vijñana-santāna) we tend to posit two constants against which and through which we cognize and evaluate all that we experience. We interpret the varying alterations of our mental experience in terms of àtman (an independent, unchanging observer or witness) and dharmas (affective, thetic, and 'objective' circumstances). Forgetting that these posited constants are constructions fabricated (parikalpita) through our attempt to suppress the anxieties and fears which change, impermanence, uncertainty, instability, and death arouse in us, we invest our invented constants with ultimate sanctity and significance. Desire-which is always the expression of a thirst that what now is should become otherwise at some future point-formulates these constants to which it can anchor itself and measure its progress toward that 'otherwise'. ${ }^{10}$

Applied to scientific inquiry, this would indicate that our whole mental preconfiguration, including our education, professional training, mental state, etc., provides the slate upon which discoveries are mapped. Also, in the same way as daily practice allows a pianist to discover ever more subtle sides to his instrument, sustained practice of the scientific method reinforces this frame of mind as the only valid way to gain knowledge. This concerns not only the actual act of, for example, designing and conducting an experiment, but also the theoretical framework, which is used to understand results of an experiment. ${ }^{11}$ The results of scientific discovery are thus not objec-

\footnotetext{
10 Lusthaus, Buddhist Phenomenology, 1.
} 
tively complete and true, but are relative to these preconditions. This is one of the reasons for the ongoing and never-ending project of scientific inquiry, which at each stage tries to overcome mistakes and misconceptions born out of these limitations. In some cases, the bias is so fundamental and severe, as to derail not just the understanding of one discipline, but change the course of history and, ultimately, the fate of our planet.

For this paper, I will focus on just two figures that were at the center of such a watershed change, Francis Bacon and René Descartes, and see in what background their thinking and doing is rooted. It goes without saying that they are merely the crest of this wave, with many surrounding figures actively involved in the whole movement.

Francis Bacon and the Suppression of Nature for the Benefit of Man

Francis Bacon (1561-1626) was a crucial figure in the development of the scientific method as we know it today. He is best known as the father of empiricism, an important step away from the scholastic learning and dependency on classical texts as opposed to direct experience as a means to gain understanding of nature. His day job was that of a statesman: legal adviser to Elizabeth I, Attorney General, and Lord Chancellor. He was a member of parliament and had the reputation of a liberal reformer; ${ }^{12}$ this was at a time when the death penalty was due for practice of witchcraft. However, his financial situation was somehow unstable; at one point he was even arrested for debt, so he had to seek favor with the influential and wealthy, at times supporting extravagant politics. His ultimate goal for scientific research was to 'improve the conditions of human existence, ${ }^{13}$ which distinguishes him from the other natural philosophers of his time,

11 This issue is covered in great detail in the monograph Objectivity by Daston and Galison.

12 Merchant, The Death of Nature, 165.

13 Rossi, Francis Bacon, 36. See also Bacon, The Works of Francis Bacon, 297. 
for whom scientific inquiry in pursue of the truth was a goal in itself, not a means for an utilitarian purpose.

His work as a judge at witch trials, which frequently used torture to extract confessions, did influence his scientific writing as exemplified here:

For you have but to follow and as it were...hound nature in her wanderings, and you will be able when you like to lead and drive her afterward to the same place again. Neither am I of opinion in this history of marvels that superstitious narratives of sorceries, witchcrafts, charms, dreams, divinations, and the like, where there is an assurance and clear evidence of the fact, should be altogether excluded. For it is not yet known in what cases, and for what cases and how far, effects attributed to superstition participate of natural causes; and therefore howsoever the use and practice of such arts is to be condemned, yet from the speculation and consideration of them (if they are diligently unravelled) a useful light may be gained, not only for a true judgment of the offenses of persons charged with such practices, but likewise for the further disclosing of the secrets of nature. Neither ought a man to make scruple of entering and penetrating into these holes and corners, when the inquisition of truth is his whole object - as your majesty has shown in your own example. ${ }^{14}$

This is from an outline on natural histories and their application to what he calls 'History Mechanical'15 from classical authors, to which is concluding comment is:

For like a man's disposition is never well known or proved till he be crossed, nor Proteus ever changed shapes till he was straitened and

14 Bacon, The Works of Francis Bacon, 296; this example is also cited in Merchant, The Death of Nature, 168.

15 This seems to be what we today refer to as 'technology', different from the mechanical philosophy of Gassendi, Descartes and Hobbes, which was the contemporary name for atomism; see Bergin and Blanning, The Seventeenth Century, 163. 
held fast; so nature exhibits herself more clearly under the trials and vexations of art than when left to herself. ${ }^{16}$

This passage has been later interpreted as to advocate 'torturing nature to reveal her secrets', which came to be associated with Bacon in later centuries. While the actual wording is debated among historians of science, ${ }^{17}$ the fact that he advocated for a method that objectifies nature and tries to forcefully extract her secrets with the aim of controlling her seems clear. It is also interesting to note, as Carolyn Merchant does, the implicit connection of dominion over nature and dominion over the female, forcefully brought home in the witch trials.

The new man of science must not think that the 'inquisition of nature is in any part interdicted or forbidden.' Nature must be 'bound into service' and made a 'slave,' put 'in constraint' and 'molded' by the mechanical arts. The 'searchers and spies of nature' are to discover her plots and secrets.

This method, so readily applicable when nature is denoted by the female gender, degraded and made possible the exploitation of the natural environment. As woman's womb had symbolically yielded to the forceps, so nature's womb harbored secrets that through technology could be wrested from her grasp for use in the improvement of the human condition. ${ }^{18}$

The first important building block of the new scientific method advocated by Bacon is thus the experiment to forcefully extract secrets from nature, and this information is used to make life more convenient for man. This is consistent with the emerging colonialism, industrialization, and capitalism, which are based on a similar mindset and together provided the backdrop for this development. ${ }^{19}$

16 Bacon, The Works of Francis Bacon, 298.

17 See Pesic, 'Wrestling with Proteus'; Merchant, "“The Violence of Impediments"'; and Pesic, 'Proteus Rebound'.

18 Merchant, The Death of Nature, 169.

19 See Harari, Sapiens, chapters 14-16. 
René Descartes and the Dualism of Mind and Matter

Another milestone is reached with Descartes' philosophical meditations. René Descartes (1596-1650) was first educated in a Jesuit college, where he was also introduced to the work of Galileo. He had the ambition to become a military officer and, after graduating from the University of Poitiers (incidentally, Francis Bacon also had spent some time there) in 1616, joined the army of a protestant Dutch state. In his first philosophical work, the Discourse on the Method, he recounted this period as follows:

That is why, as soon as I reached an age that allowed me to escape from the control of my teachers, I abandoned altogether the study of letters. And having decided to pursue only that knowledge which I might find in myself or in the great book of the world, I spent the rest of my youth travelling, visiting courts and armies, mixing with people of different character and rank, accumulating different experiences, putting myself to the test in situations in which I found myself by chance, and at all times giving due reflection to things as they presented themselves to me so as to derive some benefit from them. ${ }^{20}$

In fact he lived the unsteady life of a mercenary, in the service of the Dutch and traveled widely through the Europe of the War of Thirty Years. Here his exposure to military engineering stoked his interest in mathematics and physics. Some of his ideas concerning analytical geometry and a 'mathematical philosophy' were gained during visions he had in November 1619. He later lived in France and the Netherlands, and died in Sweden in 1650. In contrast to Bacon he did not live his life in a stable political nation, but witnessed the devastation and insecurity that ultimately cost Europe one third of its population.

Descartes is of course well known for his 'Cogito ergo sum'-'I think, therefore I am'-the conclusion of the radical doubt recounted in part four of his Discourse and the foundation for his proof of the existence of god. ${ }^{21}$ Considering that the standard

\footnotetext{
20 Descartes, Discourse on the Method, 10.
} 
method of confirming the truth of a statement at that time was recurse to authoritative texts, this was truly revolutionary and explains the great influence this short essay had on the development of modern philosophy.

But immediately afterwards I noted that, while I was trying to think of all things being false in this way, it was necessarily the case that I, who was thinking them, had to be something; and observing this truth: I am thinking therefore I exist, was so secure and certain that it could not be shaken by any of the most extravagant suppositions of the sceptics, I judged that I could accept it without scruple, as the first principle of the philosophy I was seeking. ${ }^{22}$

The other main contribution Descartes made was his exposition of the 'distinctions of body and soul', the so-called mind-body dualism. In the sixth of his Mediations on First Philosophy, he considers the question 'whether material things exist', ${ }^{23}$ to which he concludes that material things do indeed exist. He then continues with the following thought:

Next, from the very fact that I know [sciam] I exist, and that for the moment I am aware of nothing else at all as belonging to my nature or essence, apart from the single fact that I am a thinking thing, I rightly conclude that my essence consists in this alone, that I am a thinking thing. And although perhaps (or rather certainly, as I shall shortly claim) I have a body, which is very closely conjoined to me, yet because, on the one hand, I have a clear and distinct idea of myself, in so far as I am a thinking and not an extended thing, and, on the other, a distinct idea of the body, in so far as it is only an

21 Descartes was shocked by the judgment of the Catholic church upon the publication of Galileos work immediately before he finished his Discourse, (Descartes, Discourse on the Method, 50) therefore he was careful to maintain a foundation for his thought that would not receive a similar condemnation.

22 Descartes, Discourse on the Method, 28.

23 Descartes, Meditations on First Philosophy, 51. 
extended and not a thinking thing, it is certain that I am really distinct from my body, and can exist without it. ${ }^{24}$

This distinction of mind and body (or res cogitans [things in thinking] and res extensa [things with extension], as he later called it) allows Descartes to perceive the body as a mechanical device like any other machine. Many of his contemporaries had difficulties to understand this concept, so for example Princess Elisabeth of Bohemia, who writes in a letter to Descartes on May 6, 1643:

So I ask you please to tell me how the soul of a human being (it being only a thinking substance) can determine the bodily spirits, in order to bring about voluntary actions. For it seems that all determination of movement happens through the impulsion of the thing moved, by the manner in which it is pushed by that which moves it, or else by the particular qualities and shape of the surface of the latter. Physical contact is required for the first two conditions, extension for the third. You entirely exclude the one [extension] from the notion you have of the soul, and the other [physical contact] appears to me incompatible with an immaterial thing. This is why I ask you for a more precise definition of the soul than the one you give in your Metaphysics, that is to say, of its substance separate from its action, that is, from thought. ${ }^{25}$

As the subsequent exchange of letters demonstrates, Descartes has difficulties in explaining his theory to the satisfaction of the Princess. He wrote more detailed explanations in his essays De mundi (The World) and De homine (The Man), but he was afraid of being targeted by the inquisition, and did not publish them in his lifetime. Here he expounds the mechanical view of the world that results from this dualism and illustrates his understanding of how mind and body are connected with many illustrations. The link of body and mind in his view lies in the pineal gland area of the brain.

\footnotetext{
24 Descartes, Meditations on First Philosophy, 55.

25 Princess Elisabeth of Bohemia and Descartes, The Correspondence, 62.
} 
With this dualism, the separation of the inner perception and the material existence of a person is achieved, a separation of the whole into parts, without a connection. This is a conceptual expression of the concept of a separate self and, together with the violent dominion over Nature one root cause for our modern condition.

There are, of course, other contributions to the development of the scientific method and technology of dominion over nature, but here is not the place to go into details. Instead, I would like to jump ahead to the current situation, where the scientific way of thinking is so deeply engrained into every fabric of culture, that it plays a similar role to the Catholic church of the medieval and early modern age. Charles Eisenstein, following Burtt, ${ }^{26}$ takes this comparison one step further:

Science in our culture is more than a system of knowledge production or a method of inquiry. So deeply embedded it is in our understanding of what is real and how the world works, that we might call it the religion of our civilization. It isn't a revolt against truth we are seeing; it is a crisis in our civilization's primary religion. The reader might protest, 'Science is not a religion. It is the opposite of a religion, because it doesn't ask us to take anything on faith. The Scientific Method provides a way to sift fact from falsehood, truth from superstition.' In fact, the Scientific Method, like most religious formulae for the attainment of truth, rests on a priori metaphysical assumptions that we must indeed accept on faith. First among them is objectivity, which assumes among other things that the formulation and testing of hypotheses don't alter the reality in which the experiments take place. This is a huge assumption that is by no means accepted as obvious by other systems of thought.

Other metaphysical assumptions include:

- That anything real can in principle be measured and quantified

- That everything that happens does so because it is caused to happen (in the sense of Aristotelian efficient cause)

26 Burtt, The Metaphysical Foundations of Modern Science. 
- That the basic building blocks of matter are generic-for instance, that any two electrons are identical

- That nature can be described by invariant mathematical laws ${ }^{27}$

In addition to these a priori assumptions, there are also practical requirements of the scientific method as used today, such as the possibility of falsification of hypothesis, which limit the possible area of inquiry. Some of these assumptions, such as the principle that observation does not alter the state of an experiment have been called into question by the developments in Quantum physics of the last hundred years, but nevertheless they form the implicit framework for many ongoing inquiries without much hesitation. This again shows how deeply rooted these assumptions are.

To this, I would add that the assumption that any specific, individual instance can be abstracted into a class of individuals as models and these abstract models can serve as a substitute for the original context the individual is embedded into. Ecology and Systems thinking bring this aspect into focus. ${ }^{28}$ This has been a flashlight on a small number of aspects of the development of the scientific method, a topic too big to be satisfyingly treated here. Here I just wanted to mention them as a reminder to what we have to deal with.

\section{Moving Forward}

The big question, of course, is how can we get out of this mess? Since the problem is with the most basic assumptions that make up our worldview, a rational explanation of the problem alone is not sufficient, since that explanation is always borne out of the limited worldview that generated the problem in the first place. On the other hand, rational thinking has served humanity well, so we do not want and will not be able to throw it out completely. Instead, I think the

\footnotetext{
27 Eisenstein, Climate-A New Story, 245.

28 Bateson, Steps to an Ecology of the Mind; Macy, Mutual Causality; and Meadows and Wright, Thinking in Systems.
} 
solution is to put rational thinking and the scientific method of inquiry in its place in a larger framework that encompasses other means of inquiry.

In the same way as the postulations of quantum physics invalidated some of the assumptions of the elementary physics based on Newton's work, Descartes' conclusions have been called into question many times since they were formulated 400 years ago, and for the most part it has been clearly shown that they are contradictory and do not hold up scrutiny, ${ }^{29}$ however again, given that everyday experience and our whole culture seem to support the perception of a separation between body and mind, and also a self separate from others, it needs more than statements to change that perception. So we will need, quite literally, to learn to see the world in a new way, beyond the limitations of our current mindset. This brings us to the question of learning itself.

\section{How Do We Learn?}

To deal with the question of how learning takes place, Gregory Bateson in his essay 'The Logical Categories of Learning and Communication' ${ }^{30}$ has offered a distinction of different logical types of learning, which he classifies as follows:

We recapitulate and extend the definitions so far given:

- Zero learning is characterized by specificity of response, whichright or wrong - is not subject to correction.

- Learning I is change in specificity of response by correction of errors of choice within a set of alternatives.

- Learning II is change in the process of Learning I, e.g., a corrective change in the set of alternatives from which choice is made, or it is a change in how the sequence of experience is punctuated.

29 See for example Ryle, The Concept of Mind, which was first published in 1949, as well as the critical discussion by Tanney, 'Rethinking Ryle', in that volume.

30 Bateson, Steps to an Ecology of Mind, 279-308. 
- Learning III is change in the process of Learning II, e.g., a corrective change in the system of sets of alternatives from which choice is made. (We shall see later that to demand this level of performance of some men and some mammals is sometimes pathogenic.)

- Learning IV would be change in Learning III, but probably does not occur in any adult living organism on this earth. Evolutionary process has, however, created organisms whose ontogeny brings them to Level III. The combination of phylogenesis with ontogenesis, in fact, achieves Level IV. ${ }^{31}$

Learning III is the relevant category here, since what is required is a reconfiguration of the system of foundational beliefs. However, Bateson's argument stays somehow abstract and formal; he does not enter into the question of how exactly this Learning III is achieved, but simply says 'But it is claimed that something of the sort does from time to time occur in psychotherapy, religious conversion, and in other sequences in which there is profound reorganization of character. ${ }^{32}$ Turning to my specific topic now: for Chan Buddhism, this does not occur from time to time, but it is the central objective of a pedagogical device that has been developed over a couple of centuries to achieve exactly this kind of result, long before philosophical inquiry in Europe fell into the Cartesian trap.

\section{Contribution of Chan}

The specific place of Chan within the whole of Buddhism is characterized through (1) the emphasis on practice, rather than the study of scriptures, (2) a communal setting, at least at the beginning of the Chan movement in China in remote areas, and (3) a discourse about the fruits of practice that involves guidance on the path and verification of the results of practice.

Historically, Chan has considered itself in a direct lineage from

31 Bateson, Steps to an Ecology of Mind, 4.8.4.
32 Bateson, Steps to an Ecology of Mind, 4.8.5. 
the historical Buddha Śākyamuni, transmitted from India to China through Bodhidharma. ${ }^{33}$ This transmission consisted of the 'One Mind' or 'One Dharma' as, for example, seen in the Essentials of the Transmission of Mind by Chan Master Duanji of Mount Huangbo [Huangbo shan duanji chanshi chuan xin fayao 黄檗山斷際禪師傳心 法要], ${ }^{34}$ Huangbo Xiyun 黄檗希运 (-850?), but not of scriptures.

On the first day of the ninth month, the master addressed [Pei] Xiu: Ever since Great Master [Bodhi]dharma came to China, [his followers in the Chan school] have preached only the One Mind and have transmitted only the One Dharma. Transmitting the Buddha with the Buddha, [we] have not preached about any other Buddha. Transmitting the Dharma with the Dharma, [we] have not preached about any other Dharma. This Dharma is the Dharma that cannot be preached about, and this Buddha is the Buddha that cannot be grasped. They are the fundamentally pure mind. There is only this one reality, and any others are not true.

九月一日師謂休日，“自達摩大師到中國，唯說一心，唯傳一法. 以 佛傳佛, 不說餘佛. 以法傳法, 不說餘法. 法即不可說之法, 佛即不 可取之佛, 乃是本源清淨心也. 唯此一事實, 餘二則非真. ${ }^{35}$

The discourses held between master and disciples then eventually gave rise to a literature that recorded these sayings and doings, the so-called Chan yulu 語錄. ${ }^{36}$ Here we find many entries that record the questions and answers of Chan masters, some sermons they gave and even some short texts they wrote. From the tenth century onward, the

33 A good recent account of the traditional view and the modern conceptions of the spread of Chan can be found in Foulk, 'The Form and Function of Koan Literature'.

34 Tno. 2012a: 48, 381.

35 T no. 2012a: 48, 381b17-21; Translation by John McRae, Essentials, 23.

36 Japanese Goroko, on the development, see Yanagida, 'Goroku no rekishi'; Yanagida, 'The Development of the "Recorded Sayings"'; and Wittern, Das Yulu.

37 See Tsien, Paper and Printing, passim; and Wittern, Das Yulu, 40-49. 
technology of woodblock printing was adopted in Buddhist circles, with Chan associates in the front row. ${ }^{37}$ Even before the widespread printing of Chan texts, there is evidence that private records of such sayings were widely circulated and a 'case' discussed by one master was later used to challenge another master. Here is an example of how such exchanges evolved, from the entry for Xuefeng Yicun (Jp. Seppō Gison) 雪峯義存 (822-908) in the Jingde chuandeng lu 景德 傳燈錄 [Records of the Transmission of the Lamp] of 1004:

[Xuefeng] brought up the saying of the Sixth Patriarch, 'It is not the wind that moves, nor is it the flag that moves, but the hearts of the venerable sirs which move!' The master commented, 'A great Patriarch with a dragon's head and a snake's tail-better to have given twenty blows of the staff.'

因舉 “六祖云, “不是風動, 不是旛動, 仁者心動.” 師日, “大小祖師 龍頭蛇足, 好與二十拄杖.’

At that time head monk Fu of Taiyuan was in attendance and when he heard this he gnashed his teeth. 'Having just spoken like that, it would also be better that I receive twenty blows of the staff,' said the master.

時太原孚上座侍立, 聞之咬齒. 師又日, “我適來恁麼道也. 好與二 十拄杖.'

(Textual comment: Yunju Qingxi said, 'On which part should the Patriarch taste the stick, the dragon's head or the snake's tail? It is just like Xuefeng to say of himself, "It would also be good for me to taste the stick"-but still, say now, what does that have to do with the meaning of the Buddha-dharma? Although for a long time there was no one in the assembly who did not get the message, still, how would a junior brother be able to understand?'

雲居錫云, “什麼處是祖師龍頭蛇尾, 便好喫棒? 只如雪峯自道, “我 也好喫拄杖.” 且道佛法意旨作麼生? 久在眾上座無有不知, 初機兄 弟且作麼生會?’

Dongchan Ji said, 'What Xuefeng says must be taken up point by point within the assembly-whether there is not a sticking point 
somewhere, otherwise it would be called avoiding it. Avoiding aside, when the Patriarch said, "It is not the wind that moves nor is it the flag that moves", what is the meaning?'

東禪齊云, “雪峯恁麼道, 為當點檢? 別有落處? 眾中喚作自抽過, 抽 過且置, 祖師道, “不是風動, 不是幡動”作麼生?’ $)^{38}$

This saying from the Sixth Patriarch Huineng (Jp. Enō) 慧能 (638-713) was about the movement of a flag in the wind. This is a quote from the text of the Biography of the Sixth Patriarch, also from the Jingde chuandeng $l u{ }^{39}$ It most likely circulated in some written form by the time of Xuefeng. This exchange is then commented upon by Yunju Qingxi 雲居清錫 (d.u.) and by Dongchan Qi 東禪齊 (d.u.), ${ }^{40}$ who, just as Xuefeng in the first place, engage with this 'case' as if it were happening right now, adding their judgement born out of the present encounter to the record.

The Jingde chuandeng $l u$ and other Chan texts are full of this kind of inner-textual, self-referential comments, which show very clearly the way Chan masters engage directly with the present situation and in the present context, while refusing to take previous answers or comments as a definite judgment that would close the case. In effect, this technique always reflects back to the present moment and its unique constellation and context; it can not really be understood beyond this situation, and thus writing it down does not really make sense. ${ }^{41}$ This quality of freshness, which resembles a dance or a music

38 T no. 2076, 51: 16.327c17-23; translation by Whitfield, Records of the Transmission of the Lamp, 143.

39 See Yampolsky, The Platform Sutra, 80. This passage does not appear in the Dunhuang text that is the base for Yampolsky's translation, but we do have it in the textus receptus of the Platform Sutra, which dates from the Yuan (T no. 48n2008: 349c).

40 Dongchan Ji (or Qi) is one of the most frequent commentators in the Jingde chuandeng $l u$, but not much information is available about him. I suspect that he is identical with Yunju Daoqi 雲居道齊 (929-997), who also resided in the Dongchan temple in Yunzhou for some time (see Jingde chuandeng $l u, T$ no. 2076, 51: 26.428c). 
performance, is at the core of the Chan method. Although this phenomenon defies the written record, it has nevertheless filled numerous volumes, thus making the Chan school-which by its own understanding is a 'tradition outside of words and letters, a direct transmission from mind to mind' - the most prolific of all Buddhist schools in China.

As an aside, the passage quoted above illustrates another point that is essential to understand Chan and underscores the applicability of the Buddhist approach to doctrine and authority exemplified in the quote from Anguttara Nikāya 3:65 above. Here the Sixth Patriarch, one of the most influential Chan masters, and the only one who's yulu has been accorded the status of a sütra, is ridiculed for making the statement that laid the foundation for his reputation, with the request of a heavy fine like a criminal. While this makes the bystander monk Fu of Taiyuan cringe, this kind of statement is fairly common in the Chan records and should remind disciples of the limited capacity of language to express the ultimate.

There is another famous passage, which extends this attitude towards the Buddha itself: it involves the monk Danxia Tianran 丹霞 天然 (739-824), a disciple of both Mazu Daoyi 馬祖道一 (709-788) and Shitou Xiqian 石頭希遷 (700-790).

During the Yuan He era of the Tang dynasty, Tianran visited Longmen Monastery on Fragrant Mountain in Luoyang. There he became a friend of the monk Funiu.

唐元和中至洛京龍門香山, 與伏牛和尚為友.

${ }^{41}$ This was, of course, not lost on the Chan masters themselves, as early as Linji Yixuan (Jp. Rinzai Gigen) 臨濟義玄 (?-866) reminded his listeners ( $T$ no. 47: 501c): 'Students of today get nowhere because they base their understanding upon the acknowledgment of names. They inscribe the words of some dead old guy in a great big notebook, wrap it up in four or five squares of cloth, and won't let anyone look at it. "This is the Mysterious Principle," they aver, and safeguard it with care. That's all wrong. Blind idiots! What kind of juice are you looking for in such dried-up bones"' (Kirchner, Record of Linji, 27 and 260). 
Later, Tianran stayed at Huilin Temple. During some extremely cold weather, he took a wooden statue of Buddha and burned it in the fire to get warm. The temple director [got extremely upset with Tianran and] yelled: 'Why are you burning my wooden buddha?' Tianran used his staff to pull some burning embers from the fire and said, 'I'm burning this buddha to get the sacred relics from it. ${ }^{9}{ }^{32}$ The temple director said, 'How can a wooden buddha have sacred relics?' 後於慧林寺遇天大寒, 取木佛燒火, 向院主訶日, “何得燒我木佛? ’ 師以杖子撥灰日，“吾燒取舍利.’主日，“木佛何有舍利?’

Tianran said, 'Well, if it doesn't have sacred relics, let's burn a couple more of them.' The temple director was so upset that his eyebrows, eyelashes, and beard all fell out.

師日, ‘既無舍利, 更取兩尊燒. ’主自後眉鬚墮落.43

Again, this shows an iconoclastic and rebellious thread in the Chan tradition which defies tradition and ordinary rules.

However, the efforts to codify the underlying teaching method, without resorting to a canon of orthodox scriptures, have not been entirely unsuccessful either. These efforts gave rise to a mode of instruction which uses the written record to illuminate certain universal patterns and constellations, but without a fixed set of answers. ${ }^{44}$ This seems to be pretty close to a system that induces Learning III as described by Bateson.

42 During the cremation ceremony for an eminent monk there usually is a search for relics, the existence of such relics is seen as a proof for the attainment of the deceased. Tianran is mocking this belief and practice here, by claiming that if the Buddha statue is holy, this should be verifiable by producing relics.

43 Puji, Wudeng huiyuan, 110.

44 I am here reporting on the ideal way at the moment of inception; in the real world even this system with all its efforts to preserve the living interpretation of the understanding, did give rise to a fixed form of exchange, for the most part devoid of the youthful softness of the beginnings. For more information, especially on this aspect, please see Hori, Zen Sand, 5-61 and Foulk, 'The Form and Function of Koan Literature'. 
Beyond the ideal-typical and formal way of understanding the Chan records indicated above, there is also a description of the content of the experience, which adds another facet to the overall picture. Here we encounter expressions of how Chan masters perceive the process of understanding. There are as many different ways to express this as there are expressers; the most famous one is probably the Ten Ox-herding Pictures (Shiniu tu 十牛圖 based on poems by Guoan Shiyuan 廓庵師遠 (d.u.), Shigu Xiyi (d.u.) and 壞衲大璉 Huaina Dalian (d.u.) and usually accompanied with paintings. ${ }^{45} \mathrm{I}$ will limit myself here to a much shorter version of this process, which recognizes only three stages. This is from the Jiatai pudeng $l u$ 嘉泰 普燈錄, compiled by Leian Zhengshou 雷菴正受 (1147-1209) and completed in 1204 .

Master Qingyuan Weixin from Jizhou ascended the dharma seat and said: 'Before I started my study of Chan thirty years ago, I saw mountains as mountains and rivers as rivers. Later, when I gained a more intimate knowledge and had some insight, I realized that mountains are not mountains, rivers are not rivers. But now that I have got a firm base and am at ease at this place, I realize that mountains are indeed just mountains, rivers are just rivers. So now I ask you, these three ways of understanding it, are they the same or are they different? So now, if there is anybody, monk or layman who got this, come forward and show it to me!

吉州青原惟信禪師上堂日，“老僧三十年前未參禪時，見山是山，見 水是水. 及至後來親見知識，有箇入處，見山不是山，見水不是水. 而今得箇休歇處, 依前見山只是山, 見水只是水. 大眾! 這三般見解, 是同是別? 有人緇素得出, 許汝親見老僧. ${ }^{46}$

45 There is a long list of renderings and translations, see 'Oxherding Pictures', Terrebess Asia Online, https://terebess.hu/english/oxindex.html for an overview.

46 Jiatai pudeng lu, $254 \mathrm{f}$. 
What Weixin 惟信 (d.u. $)^{47}$ describes here is not an objective epistemological process, but the process of interacting with this given context of our environment, based on his own condition. The development over these thirty years did not mainly happen on the outside, but in the way his perception evolved. As he started to get some insight, he felt the distinctive qualities of mountains and rivers diminishing, but as he developed a more mature stable understanding, he was again to realize them as specific items, although now within a different setting. So these ways of understanding are indeed, on a surface level distinct, but on a deeper level there is no difference.

\section{Conclusions}

The artificial reduction of possible avenues for gaining knowledge to purely rational and seemingly objective methods has obscured a whole set of other available methods. This has lead humanity to the brink of extinction in an alienated, disenchanted universe. Specifically, the violent turn against nature, which is an essential part of the scientific worldview, as well as the distinction between mind and body, has contributed to the alienation from nature, which is the mother and nurturer of all living beings. This trend, inherent in our modern life style, has been further accelerated by the proliferation of the internet and the virtual worlds it creates. The trend to disembodiment and virtual reality is widening as we turn to AI as the new frontier of development. While we gaze at our screens and like cat pictures, the rain forests of the Amazon are burning and life forms we urgently need for our survival are lost on a daily basis. This is firstly and foremost a crisis of the mind, of the way we perceive ourselves and our surroundings, our relation to the ecosystems that support us. The way out of this can not be more of the same medicine, a technological fix to the problems technology created. What we need is a change of mind.

47 Qingyuan Weixin was a disciple of Huanglong Zuxin 黃龍祖心 (10251100 ), so most likely active before the turn of the twelfth century. 
A possible contribution of Buddhism in general and Chan Buddhism specifically is a method to return to a more holistic view of the universe, and thus regaining access to the full picture. Over the last 1500 years, Buddhist and Chan masters have developed methods to cope with the limitations of mind, and succeeded in creating an environment supportive of realizing our connection to the world around us. While not Chan or Zen per se, there is already work under way to integrate some meditation techniques into medical or educational settings. Much of this is influenced by Jon Kabat-Zinn, ${ }^{48}$ who pioneered the use of some simple techniques for stress reduction and labeled it 'mindfulness-based stress reduction' (MSBR), which led to an explosion of mindfulness as a buzzword. Another example is Arthur Zajonc, ${ }^{49}$ a physicist, who explicitly included meditation techniques in his teaching and research practices as described in Meditation as Contemplative Inquiry. What I propose here goes further and should include some of the more essential parts of the Chan curriculum mentioned above and use this to lay the epistemological foundations for an extended version of the scientific method. The details of this will have to be worked out in conjunction with the practice of changing the mind.

\section{Bibliography}

\section{Abbreviations}

$T$

Taishō shinshū daizōkyō大正新脩大藏經. See Bibliography, Secondary Sources, Takakusu and Watanabe, eds.

48 Jon Kabat-Zinn did indeed study with Zen teachers Philip Kapleau, Thich Nhat Hanh and Seung Sahn and helped found the Cambridge Zen Center in 1973.

49 Arthur Zajonc was also instrumental in organizing a series of dialogues between scientists and the Dalai Lama at the MIT and helped found the Mind and Life Institute (mindandlife.org), which aims at integrating science with contemplative practices. 


\section{Primary Sources}

Jiatai pudeng $l u$ 嘉泰普燈錄 [Records of the transmission of the lamp of the Jiatai era (1201-1204)]. 3 juan. Compiled by Leian Zhengshou 雷庵正受 (1146-1208) in 1204. References made to the Foguang Dazang Jing Bianxiu Weiyuanhui 佛光大藏經編修委 員會 edition, Kaohsiung: Foguang Temple 佛光山寺, 1995.

Jingde chuandeng lu 景德傳燈錄 [Records of the transmission of the lamp of the Jingde era]. 30 juan. By Daoyuan 道原 (d.u.) in 1004. Tno. 2076, vol. 51.

Wudeng buiyuan 五燈會元 [Comprehensive source of the five lamps]. 20 juan. Compiled by Puji 普濟 (1179-1253) and first published in 1253. Beijing: Zhonghua shuju 中華書局, 1984.

\section{Secondary Sources}

Bacon, Francis. The Works of Francis Bacon. Edited by James

Spedding. Vol 4. Cambridge Library Collection - Philosophy.

Cambridge: Cambridge University Press, 2011.

Bateson, Gregory. Steps to an Ecology of Mind: Collected Essays in Anthropology, Psychiatry, Evolution, and Epistemology.

Northvale: Aronson, 1987.

Bergin, Joseph, and Timothy C. W. Blanning. The Seventeenth Century: Europe 1598-1715. Oxford: Oxford University Press, 2000.

Bodhi, Bhikku, ed. The Numerical Discourses of the Buddha: A Translation of the Anguttara Nikàya. Boston: Wisdom Publications, 2012.

Burtt, E. A. The Metaphysical Foundations of Modern Science. New York: Dover Publication Inc., 2003. Reprint of revised 1932 edition. First published 1925 by Doubleday (New York).

Daoyuan. Records of the Transmission of the Lamp (Jingde Chuandeng Lu) Vol. 4 (Books 14-17) - The Shitou Line. Translated by Randolph S. Whitfield. Norderstedt: Books on Demand, 2017.

Daston, Lorraine, and Galison, Peter. Objectivity. New York: Zone Books, 2010. 
Descartes, René. A Discourse on the Method of Correctly Conducting

One's Reason and Seeking Truth in the Sciences. Translated with an Introduction and Notes by Ian Maclean. New York: Oxford University Press, 2006.

- Meditations on First Philosophy. With Selections from the

Objections and Replies. Translated with an Introduction and Notes by Michael Moriarty. New York: Oxford University Press, 2008.

Eisenstein, Charles. Climate-A New Story. Berkeley: North Atlantic Books, 2018.

Foulk, T. Griffith. 'The Form and Function of Koan Literature: A Historical Overview'. In The Koan: Texts and Contexts in Zen Buddhism, edited by Steven Heine, 15-45. New York: Oxford University Press, 2000. - 'The spread of Chan (Zen) buddhism'. In The Spread of Buddhism, edited by Ann Heirman and Stephan Peter Bumbacher, 433-56. Leiden: Brill, 2007.

Fuller Sasaki, Ruth, trans., Thomas Yūhō Kirchner, ed. Record of Linji. Honolulu: University of Hawai'i Press, 2009.

Goethe, Johann Wolfgang von. Scientific Studies. Edited by Douglas Miller. New York: Suhrkamp, 1988.

Harari, Yuval Noah. Sapiens: A Brief History of Humankind. Toronto: Signal, 2014.

Hori, Victor. Zen Sand: The Book of Capping Phrases for Köan Practice. Honolulu: University of Hawai'i Press, 2003.

Huangbo, Xiyun. 'Essentials of the Transmission of Mind'. In Zen Texts, translated by John R. McRae, 1-42. Berkeley: Numata Center for Buddhist Translation and Research, 2005.

Lusthaus, Dan. Buddhist Phenomenology: A Philosophical Investigation of Yogācāra Buddhism and the Ch'eng Wei-shiblun. London: RoutledgeCurzon, 2002.

Macy, Joanna. Mutual Causality in Buddhism and General Systems Theory: The Dharma of Natural Systems. Albany: State University of New York Press, 1991.

Meadows, Donella H., and Diana Wright. Thinking in Systems: A Primer. London: Earthscan, 2009.

Merchant, Carolyn. The Death of Nature: Women, Ecology, and the 
Scientific Revolution. San Francisco: Harper One, 1990.

—. "The Violence of Impediments": Francis Bacon and the

Origins of Experimentation'. Isis 99, no. 4 (2008): 731-60.

Pesic, Peter. 'Proteus rebound: Reconsidering the "torture of nature"'. Isis 99, no. 2 (2008), 304-17.

_. 'Wrestling with Proteus: Francis Bacon and the "Torture" of Nature'. Isis 90, no. 1 (1999): 81-94.

Pirsig, Robert M. Zen and the Art of Motorcycle Maintenance: An Inquiry Into Values. London: Corgi, 1976.

Princess Elisabeth of Bohemia, and Rene Descartes. The Correspondence between Princess Elisabeth of Bohemia and Rene Descartes (The Other Voice in Early Modern Europe). Edited and translated by Lisa Shapira. Chicago: Chicago University Press, 2007.

Rossi, Paolo. Francis Bacon: From Magic to Science. Chicago:

University of Chicago Press, 1968.

Ryle, Gilbert. The Concept of Mind. London: Routledge, 2009.

Takakusu Junjirō 高楠順次郎, and Watanabe Kaigyoku 渡邊海旭, eds. Taishō shinshū daizōkyō 大正新脩大藏經 [Buddhist Canon compiled under the Taishō Era (1912-1926)]. 100 vols. Tokyo: Taishō issaikyō kankōkai 大正一切經刊行會, 1924-1932.

Tanney, Julia. 'Rethinking Ryle: A Critical Discussion of the Concept of Mind'. In The Concept of Mind, by Gilbert Ryle, ix-lviii. London: Routledge, 2009.

Thoreau, Henry David. The Writings of Henry David Thoreau in 20 Volumes (Vol. 8). Boston: The Riverside Press and New York: Houghton, Mifflin \& Company, 1906.

Tsien, Tsuen-hsuin. Paper and Printing. Edited by Joseph Needham. Cambridge: Cambridge University Press, 2001.

Wittern, Christian. Das Yulu des Chan-Buddhismus: Die Entwicklung vom 8.-11. Jabrbundert am Beispiel des 28. Kapitels des Jingde Chuandenglu (1004) [The Yulu of Chan-Buddhism. Development from the eighth to eleventh century in the example of chapter 28 of the Jingde chuandeng lu (1004)]. Berlin: Peter Lang, 1998.

Yampolsky, Philip B. The Platform Sutra of the Sixth Patriarch; the Text of the Tun-buang Manuscript with Translation, Introduction, 
and Notes. New York: Columbia University Press, 1967.

Yanagida, Seizan. 'The Development of the "Recorded Sayings" Texts of the Chinese Ch'an School'. In Early Ch'an in China and Tibet, edited by Whalen Lai and Lewis Lancaster, translated by John R. McRae, 185-205. Berkeley: Asian Humanities Press, 1983.

Yanagida Seizan 柳田聖山. 'Goroku no rekishi: Zen bunken no seiritsushi teki kenkyū' 語録の歴史一禪文獻の成立史的研究 [History of the recorded sayings: research on the history of the genesis of Chan documents]. Tōhō Gakuhō 東方學報 [Journal of Oriental Studies] 57 (1985): 211-663.

Zajonc, Arthur. Meditation as Contemplative Inquiry: When Knowing Becomes Love. Great Barrington: Lindisfarne Books, 2009. 